\title{
The effect of hydrothermal treatment on industrial wastewater: Hungary as a case study
}

\author{
MAHMOOD AL RAMAHI ${ }^{1 *}$ (D), SÁNDOR BESZÉDES ${ }^{2}$ and \\ GÁBOR KESZTHELYI-SZABÓ ${ }^{2}$
}

\footnotetext{
${ }^{1}$ Doctoral School of Environmental Sciences, University of Szeged, Dugonics tér 13, H-6724 Szeged, Hungary

${ }^{2}$ Department of Process Engineering, University of Szeged, Faculty of Engineering, Moszkvai krt. 9, H-6725 Szeged, Hungary
}

\section{CONFERENCE FULL PAPER}

Received: January 31, 2020 • Accepted: September 17, 2020

Published online: October 17, 2020

(C) 2020 The Author(s)

\begin{abstract}
Industrial wastewater is a growing environmental challenge due to its high concentrations of organics and its limited biological degradability. Up to date, however, no published work discussed industrial wastewater characterization, which is the focus of this study. Moreover, the effect of hydrothermal treatment on the chemical oxygen demand (COD) removal and the soluble chemical oxygen demand (SCOD) release was investigated in this work. Wastewater samples were collected from different industrial sites and characterized in order to determine their initial properties. It was summarized that the salinity of wastewater estimated by EC was relatively low, and its $\mathrm{pH}$ values were in the acceptable range. On the other hand, however, high values of sodium absorption ratio (SAR) were obtained in all samples post to hydrothermal treatment. Nonetheless, our results revealed higher SCOD release post to hydrothermal treatment suggesting better efficiency of COD removal obtained by this treatment technique.
\end{abstract}

\section{KEYWORDS}

wastewater, sodium absorption ratio, hydrothermal treatment, anaerobic digestion

\footnotetext{
*Corresponding author. E-mail: Mahmoud.alramahi@mk.u-szeged.hu
} 


\section{INTRODUCTION}

Increasing amount of industrial wastewater is discharged every year as a result of human activities. Since the 1980s, an approximate of 10,000 new chemical compounds are being introduced to the industrial sector annually. Hence, the characteristics of the discharged industrial effluents vary depending on season and collection point. Moreover, industrial effluents vary in their composition depending on the type of the industry and materials used. In general, the composition of effluents includes a range of constituents such as biodegradable and non-biodegradable organics, inorganics and inhibitory substances. Therefore, the industrial effluents may be nutrient deficient and contain high concentrations of heavy metals (Mhlanga \& Brouckaert, 2012). In summary, the flow pattern of industrial effluent streams is mainly influenced by the nature of operations and it differs by season and location, therefore, a comprehensive understanding of its characterization is essential.

The discharged wastewater contains significant amounts of biomass consisting of proteins, carbohydrates and lipids. As mentioned above, the specific characteristics of the discharged wastewater vary depending on the methods of operation and hence, the relative proportions of fats, proteins and carbohydrates differ constantly (Al Ramahi et al., 2020). Some of these compounds result in biodegradability difficulties caused by sludge flotation, which is attributed to the presence of fats (Perle et al., 1995). Moreover, the high rate of fat adsorption may limit the transport of soluble substrates and consequently cause the conversion rate in the substrates to decrease (Atallah et al., 2020).

Anaerobic digestion (AD) has long been recognized as an effective treatment technique for municipal and industrial wastewater. The process is meant to break down sludge gel networks and reduce water affinity of sludge. The series of biological processes in $\mathrm{AD}$ are: hydrolysis, acidogenesis, acetogenesis, and methanogenesis (Al Ramahi et al., 2020). Hydrolysis is the first step of $\mathrm{AD}$ and it is agreed upon to be the rate limiting step for the entire process (Jin et al., 2019). During hydrolysis (the wet disintegration) of the complex compounds, complex macromolecular structures such as EPS are converted into simple soluble organics. Pre-treatment techniques are suggested to facilitate the hydrolysis step in order to achieve faster disintegration and higher degradation efficiency. Specifically, hydrothermal treatment has been proven to be one of the most effective aid which is expected to decrease polymerization and crystallinity of the cellulose, and therefore, improve the enzymatic degradation of the organics within the discharged wastewater (Gao et al., 2018).

The two common parameters that are used to investigate the composition of wastewater are the biochemical oxygen demand $\left(\mathrm{BOD}_{5}\right)$ and chemical oxygen demand (COD) (Yap et al., 2017). $\mathrm{BOD}_{5}$ is a measure of the amount of the dissolved oxygen consumed by bacteria in a 5 day period at $20^{\circ} \mathrm{C}$. While regulations for BOD values vary in different locations, the typical acceptable range must not exceed $300 \mathrm{mg} / \mathrm{L}$ in most places (Yap et al., 2017). On the other hand, COD is measured chemically by digestion with acids and is used to determine the amount of total organics (including non-biodegradable organics) within the wastewater (Peterson et al., 2008). $\mathrm{COD} / \mathrm{BOD}_{5}$ ratio has been commonly used as an indicator for the biodegradation assessment of wastewater. Usually, their value does not exceed 2.5 for domestic wastewaters and 10 for industrial wastewaters (Zhen et al., 2017).

A remarkable technological development in the field of wastewater treatment has taken place in Hungary to meet the high international quality standards since the EU accession. For 
example, between the year of 2011 and 2015, an equivalent of EUR 2.4 billion was assigned to develop more than 500 operating wastewater treatment plants in the country; more than $50 \%$ of their capacity was designed to treat wastewater with high organic contents produced by the industrial sector (Hungarian Central Statistical Office, 2014). Specifically, the food industry produces the highest organic concentrated wastewaters of all sectors (Gallipoli et al., 2014). Up to date, however, no published work discussed the characterization and biodegradability of industrial wastewater in Hungary, neither the effect of hydrothermal treatment on its characteristics and biodegradability, which is the focus of this study. Wastewater samples were collected and analyzed from three different sites, including meat processing wastewater and dairy wastewater collected from local factories in Szeged. On the other hand, the municipal wastewater was collected from the wastewater treatment plant in Kiskunhalas city. Post to analysis, hydrothermal treatment experiments were carried out to investigate the effect of hydrothermal treatment on the discharged wastewater as detailed below.

\section{MATERIALS AND METHODS}

Hydrothermal treatment experiments were performed by placing $250 \mathrm{~mL}$ of wastewater in a microwave oven $(2,450 \mathrm{MHz}$ frequency) at different treatment times, ranging from 0 to $6 \mathrm{~min}$. Experiments were carried in polytetrafluoroethylene (PTFE) vessels for effective microwave dissipation in samples. A cover was employed to avoid evaporation and hot spots formation, as well as any volatile loss during the treatment.

Prior and post to treatment, samples were stored in $20 \mathrm{~mm}$ bottles and characterized based on the following physicochemical parameters: $\mathrm{pH}$, total solids (TSs), volatile solids (VSs), and ash. TS, VS, and ash were determined following the American Public Health Association (APHA) method. $\mathrm{pH}$ and electrical conductivity (EC) were measured using special electrodes and $\mathrm{pH}$ meter (CONSORT C535). All analyses were duplicated and results were reported as mean value with standard errors.

$\mathrm{BOD}_{5}$ was measured by standard methods 5210B using BOD-System OxiDirect (Lovibond), the initial dissolved oxygen content was measured and then samples were incubated for 5 days at $20{ }^{\circ} \mathrm{C}$ to determine $\mathrm{BOD}_{5}$ measurements. $\mathrm{COD}$ was measured using medium range tubes in accordance with EPA 410.4 and ISO 15705:2002 standards. For COD analysis, samples were diluted with Double Distilled Water (DDW) at 1:10 ratio prior to thermos digestion $\left(150{ }^{\circ} \mathrm{C}\right.$ for $2 \mathrm{~h}$ ). Statistical analysis was performed to determine if differences between the characteristics were significant. One-way ANOVA (single factor) was performed in Microsoft Excel 2016 at 95\% confidence level and when a significant difference was detected, post hoc pairwise multiple comparisons were calculated.

\section{RESULTS AND DISCUSSION}

\section{Wastewater characterization}

All collected samples were characterized and evaluated in order to determine the initial properties and potential digestibility (Table 1 ). The organic fraction (volatile solids) values ranged between $53 \%$ and $60 \%$ with no significant difference $(P>0.05)$. Total dissolved solids (TDSs) average was between 788 and $715 \mathrm{mg} / \mathrm{L}$ for both meat processing and municipal wastewater, 
Table 1. Wastewater characterization

\begin{tabular}{lccc}
\hline Parameter & Dairy wastewater & Meat processing wastewater & Municipal wastewater \\
\hline TS $(\mathrm{g} / \mathrm{L})$ & $4.0^{\mathrm{a}}$ & $2.5^{\mathrm{a}}$ & $3.0^{\mathrm{a}}$ \\
& $(0.3)$ & $(0.4)$ & $(1.1)$ \\
VS (\%) of TS & $60^{\mathrm{a}}$ & $53^{\mathrm{a}}$ & $54^{\mathrm{a}}$ \\
& $(1)$ & $(7)$ & $(4)$ \\
TDS $(\mathrm{mg} / \mathrm{L})$ & $153^{\mathrm{a}}$ & $788^{\mathrm{b}}$ & $715^{\mathrm{b}}$ \\
& $(2)$ & $(72)$ & $(81)$ \\
$\mathrm{pH}$ & $5.35^{\mathrm{a}}$ & $6.05^{\mathrm{b}}$ & $7.08^{\mathrm{c}}$ \\
& $(0.10)$ & $(0.01)$ & $(0.01)$ \\
EC $(\mathrm{mS} / \mathrm{cm})$ & $2.15^{\mathrm{a}}$ & $1.25^{\mathrm{b}}$ & $1.26^{\mathrm{b}}$ \\
& $(0.25)$ & $(0.01)$ & $(0.19)$ \\
\hline
\end{tabular}

${ }^{*}$ Samples were taken from the wastewater plant located in Kiskunhalas city, Hungary.

Standard error is shown in parentheses. Statistical differences are indicated by different superscript letters.

respectively. On the other hand, low values of TDS were reported in dairy wastewater, as low as $150 \mathrm{mg} / \mathrm{L}$. This may be attributed to the high rate of fat adsorption that may limit the transport of soluble substrates and consequently cause the conversion rate to decrease (Atallah et al., 2020).

On another note, the salinity of wastewater represented by EC was relatively low $(<2.5)$, and $\mathrm{pH}$ values were within the acceptable range (5-7). However, the potential of the aqueous phase as a liquid fertilizer depends not only on the salinity, but also on the sodium absorption ratio (SAR). SAR is a measure of the suitability of water for its use in agricultural irrigation, as determined by the concentrations of $\mathrm{Na}^{+}$, relative to those of $\mathrm{Ca}^{+2}$ and $\mathrm{Mg}^{+2}$. High Sodicity of wastewater, caused by high sodium concentrations is expected to cause soil swelling and dispersion, surface crusting and pore plugging leading to reduced infiltration and increased runoff within the soil clays (Oster, 1994). Still, the presence of the divalent ions, namely $\mathrm{Ca}^{+2}$ and $\mathrm{Mg}^{+2}$, can mitigate the impact of sodicity (Mau et al., 2016). Table 2 shows the concentrations of $\mathrm{Na}^{+}, \mathrm{Ca}^{+2}$, and $\mathrm{Mg}^{+2}$ for all collected samples, indicating high values of SAR.

Moreover, all measured samples exceeded the allowable discharge levels of COD $(300 \mathrm{mg} / \mathrm{L})$, and $\mathrm{BOD}_{5}(50 \mathrm{mg} / \mathrm{L})$ (Table 3). Interestingly, however, the meat processing wastewater has significantly higher concentrations of $\mathrm{BOD}_{5}$ than those obtained in dairy wastewater $(P<0.05)$. On the other hand, concentrations of $\mathrm{BOD}_{5}$ for municipal wastewater were slightly higher than expected (Uma Rani et al., 2014). The relatively high BOD values in the discharged wastewater may be a result of the elevated concentrations of fats. However, the relatively low $\mathrm{COD} / \mathrm{BOD}_{5}$ ratio $(<10)$ suggests a degradable effluent with high concentrations of organics. In summary,

Table 2. Concentrations of key elements

\begin{tabular}{lccc}
\hline Type & Sodium $(\mathrm{Na})$ & Calcium $(\mathrm{Ca})$ & Magnesium $(\mathrm{Mg})$ \\
\hline Dairy wastewater & 457.00 & 58.10 & 7.45 \\
Industrial wastewater & 678.00 & 48.00 & 12.10 \\
Municipal wastewater & 397.00 & 39.90 & 6.60 \\
\hline
\end{tabular}

Standard errors are not reported due insufficient sets of data. 
Table 3. COD and BOD values

\begin{tabular}{lccc}
\hline Parameter & $\mathrm{BOD}_{5}(\mathrm{~g} / \mathrm{L})$ & $\mathrm{COD}(\mathrm{g} / \mathrm{L})$ & ${\mathrm{COD} / \mathrm{BOD}_{5} \text { ratio }}^{1.9^{\mathrm{a}}}$ \\
\hline Municipal wastewater & $(0.2)$ & $2.0^{\mathrm{a}}$ & 1.1 \\
Dairy wastewater & $2.2^{\mathrm{a}}$ & $(0.2)$ & 1.6 \\
& $(0.0)$ & $3.5^{\mathrm{a}}$ & 1.0 \\
Meat processing wastewater & $3.0^{\mathrm{b}}$ & $(0.8)$ & \\
& $(0.0)$ & $2.9^{\mathrm{a}}$ & \\
\hline
\end{tabular}

${ }^{*}$ Samples were taken from the wastewater plant located in Kiskunhalas city, Hungary.

Standard error is shown in parentheses. Statistical differences are indicated by different superscript letters. $\mathrm{COD} / \mathrm{BOD}_{5}$ ratio was calculated using the average measurements neglecting the reported standard errors obtained.

$\mathrm{COD}, \mathrm{BOD}, \mathrm{pH}, \mathrm{TS}$, and the major elements concentrations were all beyond the allowable discharge limits, and thus, onsite solutions are needed and required.

\section{The effect of thermal treatment on chemical oxygen demand concentrations and soluble chemical oxygen demand release}

Fig. 1 shows the COD solubilization during hydrothermal treatment for all samples. COD concentrations tended to increase to their maximal concentration at $225^{\circ} \mathrm{C}$. COD values were about 7,230, 7,340 and 7,800 $\mathrm{mg} / \mathrm{L}$ for municipal, dairy and meat processing wastewater, respectively. No increase in COD solubilization was observed beyond that (data not shown) due to the denaturation and/or transformation into other compounds as a result of high processing temperature. The increase in soluble chemical oxygen demand (SCOD) concentrations after hydrothermal treatment is attributed to the transfer of organic substances from non-soluble materials into soluble materials, as well as to the release of the intracellular organic materials into the medium as a result of cell wall disintegration. Hence, the increase in SCOD levels was due to the high intensity of the chemical reactions beyond the boiling

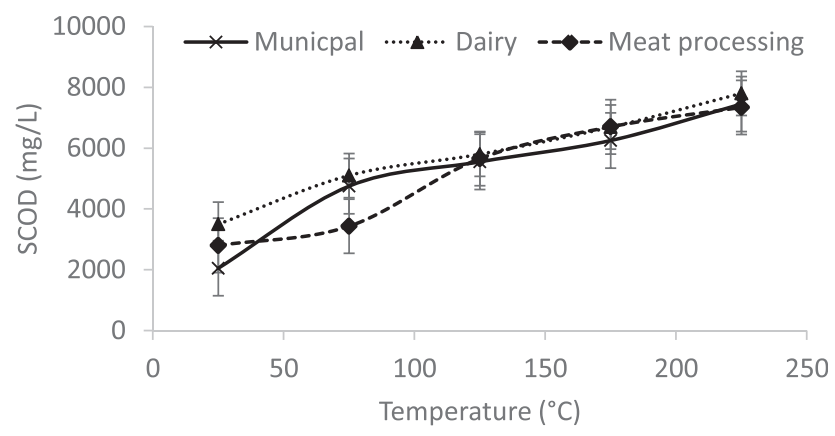

Fig. 1. COD solubilization during heat treatment. Error bars represents the standard errors 
temperature, including dehydration and decarboxylation, in which organics are transferred into the aqueous phase.

\section{CONCLUSION}

Different types of wastewater were characterized mainly based on their $\mathrm{COD} / \mathrm{BOD}_{5}$ ratio and their organic matter content. Results suggested a degradable effluent with high organic matter content, suitable for AD. Still, the extensive observations of COD and BOD measurements show high variation, probably caused by the seasonal variations in climatic conditions, social customs, water supply characteristics and water availability. Therefore, the correlation should be periodically reevaluated. SCOD release tended to increase significantly during hydrothermal treatment to its maximal concentration at $225{ }^{\circ} \mathrm{C}(6 \mathrm{~min})$ suggesting that thermal treatment technique could be an efficient pretreatment technique prior to $\mathrm{AD}$. However, further investigation is needed to evaluate the technological feasibility of this pretreatment on a large scale, as well as its economic aspect.

\section{LIST OF ABBREVIATIONS}

DOC dissolved organic carbon;

EPS extracellular polymeric substances;

TN total nitrogen;

COD chemical oxygen demand;

SCOD soluble chemical oxygen demand;

SAR sodium absorption ratio

\section{REFERENCES}

Al Ramahi, M., Keszthelyi-Szabó, G., and Beszédes, S. (2020). Improving biogas production performance of dairyactivated sludge via ultrasound disruption priorto microwave disintegration. Water Science and Technology, 81: 1231-1241. https://doi.org/10.2166/wst.2020.216.

Atallah, E., Zeaiter, J., Ahmad, M.N., Kwapinska, M., Leahy, J.J., and Kwapinski, W. (2020). The effect of temperature, residence time, and water-sludge ratio on hydrothermal carbonization of DAF dairy sludge. Journal of Environmental Chemical Engineering, 8: 103599. https://doi.org/10.1016/j.jece.2019. 103599.

Gallipoli, A., Gianico, A., Gagliano, M.C. and Braguglia, C.M. (2014). Potential of high-frequency ultrasounds to improve sludge anaerobic conversion and surfactants removal at different food/inoculum ratio. Bioresource Technology, 36: 2541-2550. https://doi.org/10.1016/j.biortech.2014.02.084.

Gao, Y., Liu, Y., Zhu, G., Xu, J., Xu, H., Yuan, Q., Zhu, Y., Sarma, J., Wang, Y., Wang, J. and Ji, L. (2018). Microwave-assisted hydrothermal carbonization of dairy manure: Chemical and structural properties of the products. Energy, 36: 4048-4056. https://doi.org/10.1016/j.energy.2018.09.185. 
Jin, H., Yan, D., Zhu, N., Zhang, S. and Zheng, M. (2019). Immobilization of metal(loid)s in hydrochars produced from digested swine and dairy manures. Waste Management, 88: 10-20. https://doi.org/10. 1016/j.wasman.2019.03.027.

Mau, V., Quance, J., Posmanik, R., and Gross, A. (2016). Phases' characteristics of poultry litter hydrothermal carbonization under a range of process parameters. Bioresource Technology, 219: 632-642. https://doi.org/10.1016/j.biortech.2016.08.027.

Mhlanga, F.T. and Brouckaert, C.J. (2012). Characterisation of wastewater for modelling of wastewater treatment plants receiving industrial. Effluent, 39: 403-408.

Oster, J.D. (1994). Irrigation with poor quality water. Agricultural Water Management, 25: 271-297. https://doi.org/10.1016/0378-3774(94)90064-7.

Perle, M., Kimchie, S., and Shelef, G. (1995). Some biochemical aspects of the anaerobic degradation of dairy wastewater. Water Research, 29: 1549-1554. https://doi.org/10.1016/0043-1354(94)00248-6.

Peterson, A.A., Vogel, F., Lachance, R.P., Fröling, M., Antal, M.J., and Tester, J.W. (2008). Thermochemical biofuel production in hydrothermal media: a review of sub- and supercritical water technologies. Energy \& Environmental Science, 1: 32-65. https://doi.org/10.1039/b810100k.

Uma Rani, R., Adish Kumar, S., Kaliappan, S., Yeom, I.T., and Rajesh Banu, J. (2014). Enhancing the anaerobic digestion potential of dairy waste activated sludge by two step sono-alkalization pretreatment. Ultrasonics Sonochemistry, 21: 1065-1074. https://doi.org/10.1016/j.ultsonch.2013.11.007.

Yap, M.W., Mubarak, N.M., Sahu, J.N., and Abdullah, E.C. (2017). Microwave induced synthesis of magnetic biochar from agricultural biomass for removal of lead and cadmium from wastewater. Journal of Industrial Engineering Chemistry, 45: 287-295. https://doi.org/10.1016/j.jiec.2016.09.036.

Zhen, G., Lu, X., Kato, H., Zhao, Y. and Li, Y.Y. (2017). Overview of pretreatment strategies for enhancing sewage sludge disintegration and subsequent anaerobic digestion: Current advances, full-scale application and future perspectives. Renewable and Sustainable Energy Reviews, 69: 559-577. https://doi.org/ 10.1016/j.rser.2016.11.187.

Open Access. This is an open-access article distributed under the terms of the Creative Commons Attribution 4.0 International License (https://creativecommons.org/licenses/by/4.0/), which permits unrestricted use, distribution, and reproduction in any medium, provided the original author and source are credited, a link to the CC License is provided, and changes - if any - are indicated. (SID_1) 